\title{
STUDI LITERATUR DISFUNGSI SEKSUAL AKIBAT COVID 19
}

\author{
Zainiah \\ Program Studi Ners - Universitas Nurul Jadid \\ E-mail: zainiah990@gmail.com \\ Setiyo Adi Nugroho \\ Dosen Pembimbing Universitas Nurul Jadid \\ E-mail: Setiyo666@gmail.com
}

\begin{abstract}
Abstrak
Latar belakang : COVID-19 berdampak pada beberapa aspek kehidupan manusia sehingga dapat mempengaruhi kesejahteraan hidup seseorang. Salah satu hal yang dapat digunakan sebagai bentuk coping untuk menghadapi masa pandemi yang mendatangkan stres untuk sebagian orang ini adalah aktivitas seksual yang pada akhirnya dapat menyebabkan munculnya disfungsi seksual.

Metode: Penelitian ini bertujuan untuk melakukan kajian literatur dampak covid 19 terhadap disfungsi seksual. Pengambilan data dilakukan dengan mereview beberapa jurnal penelitian.

Hasil : di dapatkan 20 artikel (Google Cendekia 5 artikel, science direx 10 artikel, elsiver 5 artikel artikel,) 12 artikel yang di keluarkan tidak sinkron dengan topik pembahasan dan tidak membahas tentang Disfungsi seksual di era pandemi. 8 artikel full text. hasil Di antara peserta karantina yang melanjutkan untuk terlibat dalam aktivitas seksual, 52,04\% melaporkan peningkatan setidaknya satu dari 14 aktivitas seksual: 145 orang $(25,66 \%)$ dilaporkan lebih sering masturbasi sendiri. 114 orangS $(20,18 \%)$ melaporkan melakukan lebih banyak hubungan seksual dengan pasangannya, dan 110 orang $(19,47 \%)$ melaporkan menonton lebih banyak pornografimereka sendiri.

Kesimpulan : Masih belum ditemukan solusi yang tepat dalam masalah pengaruh covid-19 dengan disfungsi seksual. Penelitian ini lebih lanjut diperlukan untuk menentukan pengaruh covid 19 terhadap disfungsi seksual . Hal ini mendorong kita untuk merenungkan mental dan seksual konsekuensi yang kami anggap sama pentingnya.
\end{abstract}

Kata kunci : covid 19, disfungsi seksual 
a. Latar Belakang

Covid 19 menjadi skenario terburuk yang menjadi ancaman bagi manusia. Sejak pertama kali COVID-19 terkonfirmasi di Cina pada akhir Desember 2019.Penyebaran virus Corona ini sangat cepat bahkan sampai ke lintas negara. Penyebaran virus Corona yang telah meluas ke berbagai belahan dunia membawa dampak pada masalah fisik, perekonomian baik dari sisi perdagangan, investasi dan pariwisata, sehingga dapat memunculkan Resiko kecemasan dan depresi bahkan disfungsi seksual pada pasien yang terpapar covid 19 yang terpaksa tinggal di karantina ${ }^{1}$.

Di Indonesia telah terkonfirmasi positif COVID-19 pada periode yang sama sebanyak 3.804.943 orang dengan jumlah kematian mencapai 115.096 orang dan 3.289.718 orang dinyatakan sembuh. Dimana Indonesia memperingkati nomer 3 dengan 34.379 kasus setiap harinya ${ }^{2}$. Kontak langsung dengan permukaan yang terinfeksi, dinyatakan sebagai pandemi oleh Organisasi Kesehatan Dunia (WHO) di Maret 2020 dan memicu semua negara untuk mengambil yang luar biasa tindakan ${ }^{3}$. Hampir semua organisasi (ilmiah, sportif,rekreasi, dll.) telah dibatalkan dan perjalanan telah terbatas. Karantina dan jam malam telah menjadi setiap hari rutinitas dan konsep jarak sosial telah menjadi kenormalan baru kita, bahkan dalam keluarga, menyebabkan signifikan gangguan dalam banyak hubungan sosial ${ }^{4}$.

WHO merangkum definisi dari kesehatan seksual sebagai fisik, emosional, mental, dan sosial kesejahteraan individu.

\footnotetext{
${ }^{1}$ Liu N, Zhang F, Wei C, et al. Prevalence and predictors of PTSS during COVID-19 outbreak in China hardest-hit areas: Gender differences matter. Psychiatry research 287 (2020): 112921

${ }^{2}$ Kementrian Kesehatan Indonesia. Data Covid-19 Indonesia 31 Juli 2021

${ }^{3}$ Torales J, O’Higgins M, Castaldelli-Maia JM, Ventriglio A. The outbreak of COVID-19 coronavirus and its impact on global mental health. Int J Soc Psychiatry. 2020;66:317-20.

${ }^{4}$ World Health Organization. Naming the coronavirus disease (COVID-19) and the virus that causes it. World Health Organization; 2020. https://www.who.int/emergencies/diseases/novelc oronavirus-2019/technical-guidance/naming-thecoronavirusdisease-(covid-2019)-and-the-virusthat-causes-it
}

Di sisi lain, seksual disfungsi dapat digambarkan sebagai kondisi apa pun yang mencegah individu dari kepuasan dengan aktivitas seksual. Setiap tahap hubungan seksual. Dengan cara ini, bukti yang konsisten menunjukkan bahwa selain penyebab organik, (vaskular, hormonal, neurogenik, farmakologis) disfungsi seksual, penyebab psikogenik, seperti kecemasan dan depresi juga memiliki efek negatif pada kehidupan seksual, di keduanya pria dan wanita 5 .

Penambahan disfungsi seksual dapat memperburuk psikopatologi yang sudah ada dan membuat lingkaran setan . Selain itu, dalam sebuah studi tentang Hedon pada disfungsi seksual laki-laki, ditekankan bahwa juga berdampak negatif pada pasangan dan akibatnya pada hubungan. Dalam penelitian ini, kami bertujuan untuk mengevaluasi perubahan dalam kehidupan seksual pasangan menikah atau tinggal bersama di Turki sampel selama masa pandemi COVID-19 yang telah berlangsung lama ${ }^{6}$.

Sebagian besar studi COVID-19 yang dilakukan hingga saat ini berfokus pada penilaian dampak pandemi terhadap kesehatan fisik. Hal ini mendorong kita untuk merenungkan mental dan seksual konsekuensi yang kami anggap sama pentingnya. Guanjian Li dkk. dampak COVID-19 terhadap kesehatan seksual, yang bermanifestasi sebagai penurunan hasrat dan frekuensi seksual hubungan seksual akibat COVID-197. Selain itu, Pedrozo-Pupo dkk. mempelajari dampak dari pandemi stres dan mencatat bahwa $15 \%$ peserta memiliki tingkat stres yang lebih tinggi karena COVID-19 pandemi $^{8}$.

\footnotetext{
${ }^{5}$ World Health Organization. Sexual and reproductive health: defining sexual health. WHO; 2006. https://www.who.int/ reproductivehealth/topics/sexual_health/sh_defini tions/en/.

${ }^{6}$ Kroenke K, Spitzer RL, Williams JB. The PHQ-9: validity of a brief depression severity measure. J Gen Intern Med. 2001;16: 606-13

${ }^{7}$ Dunn KM, Croft PR, Hackett GI. Association of sexual problems with social, psychological, and physical problems in men and women: a cross sectional population survey. J Epidemiol Community Health. 1999;53:144-8.
} 
Berdasarkan uraian-uraian diatas, artikel ini akan mencoba menjelaskan terkait pengaruh pandemik Covid 19 terhadap disfungsi seksual.

b. Metode

Metode penelitian yang kami gunakan disini adalah literatur review dengan menggunakan basis data elektronik melalui jurnal dari Internasional maupun Nasional. Google Cendekia, science direx, elsiver, Pubmed digunakan sebagai database Jurnal utama untuk studi referensi ini. Pertama- tama, kata kunci digabungkan selama pencarian Jurnal yang berfokus pada Pengaruh COVID-19 dengan disfungsi seksual.

c. Hasil

Pencarian jurnal awalnya di dapatkan 20 artikel (Google Cendekia 5 artikel, science direx 10 artikel, elsiver 5 artikel artikel,) 12 artikel yang di keluarkan tidak sinkron dengan topik pembahasan dan tidak membahas tentang Disfungsi seksual di era pandemi. 8 artikel full text memenuhi kriteria seperti yang tercantum pada gambar di bawah ini :

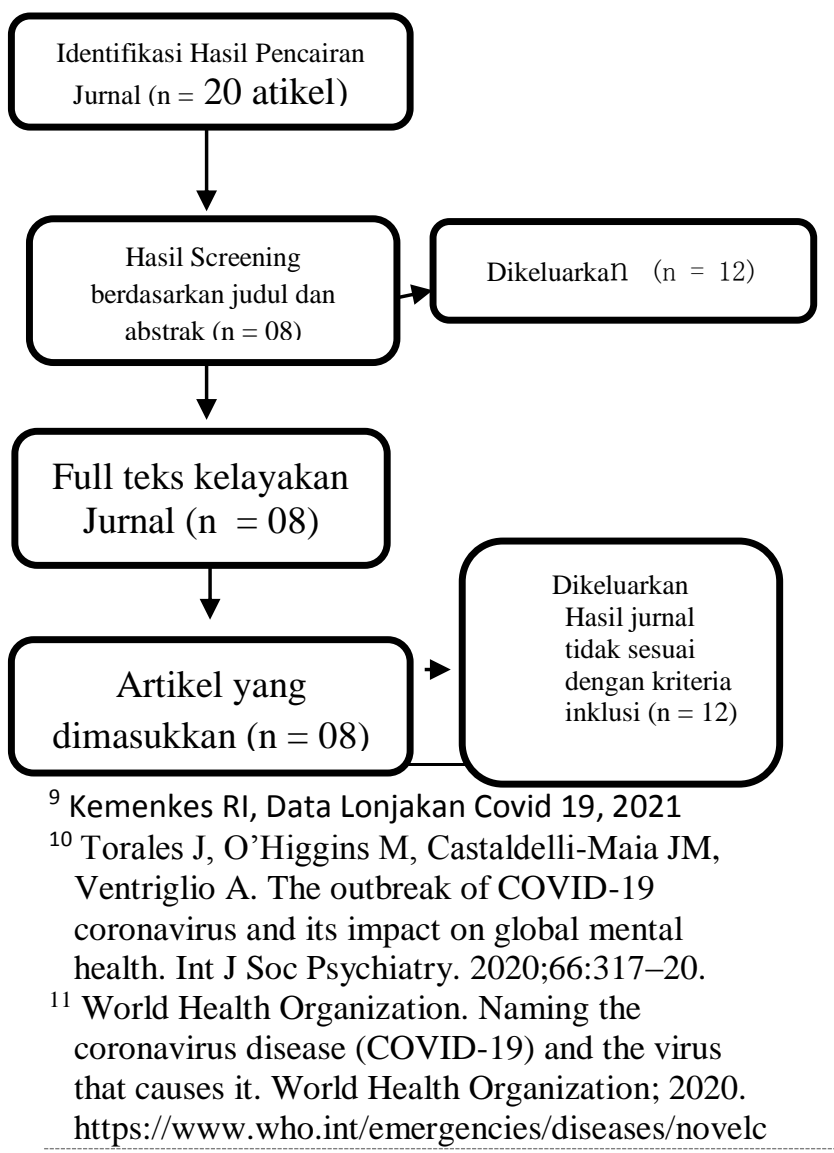

D. Pembahasan

Berdasarkan hasil study referensi, Penyebaran Covid 19 yang sangat cepat dan telah bersetatus pandemic merupakan masalah yang paling membebani di dunia saaat ini. Di Indonesia telah terkonfirmasi positif COVID-19 pada periode yang sama sebanyak 3.804.943 orang dengan jumlah kematian mencapai 115.096 orang dan 3.289.718 orang dinyatakan sembuh ${ }^{9}$. Dengan lonjakan kasus 34.479 setiap harinya.

Dengan tingginya kasus covid setiap harinya memicu semua negara untuk mengambil yang luar biasa tindakan ${ }^{10}$. Hampir semua organisasi (ilmiah, sportif,rekreasi, dll.) telah dibatalkan dan perjalanan telah terbatas. Karantina dan jam malam telah menjadi setiap hari rutinitas dan konsep jarak sosial telah menjadi kenormalan baru kita, bahkan dalam keluarga, menyebabkan signifikan gangguan dalam banyak hubungan sosial ${ }^{11}$.

Pasien yang terpapar covid-19 akan mendapatkan karantina oleh tenaga kesehatan. Pasien covid yang berada dalam karantina dan mengisolasi diri jauh dari kerumunan dan keluarga serta orang terdekat, dengan adanya karantina memungkinkan muncul Resiko kecemasan dan depresi bahkan disfungsi seksual karna jauh dari seseorang atau keluara pada pasien yang terpapar covid 19 yang terpaksa tinggal di karantina ${ }^{12}$ meskipun peneliti belum menemukan data lebih lanjut.

Seperti diketahui, kualitas dan memuaskan kehidupan seksual memiliki efek positif pada sosial dan hubungan sehari-hari serta pada kehidupan intim banyak orang individu WHO merangkum definisi dari kesehatan seksual sebagai fisik, emosional, mental, dan sosial

oronavirus-2019/technical-guidance/naming-thecoronavirusdisease-(covid-2019)-and-the-virusthat-causes-it

12 Baca artikel CNN Indonesia "Masa Karantina Mengubah Dorongan Seksual" selengkapnya di sini: https://www.cnnindonesia.com/gayahidup/20200427063111-284-497482/masakarantina-mengubah-dorongan-seksual 
kesejahteraan individu. Di sisi lain, seksual disfungsi dapat digambarkan sebagai kondisi apa pun yang mencegah individu dari kepuasan dengan aktivitas seksual. Setiap tahap hubungan seksual. Dengan cara ini, bukti yang konsisten menunjukkan bahwa selain penyebab organik, (vaskular, hormonal, neurogenik, farmakologis) disfungsi seksual, bisa penyebab psikogenik, seperti kecemasan dan depresi seperti yang dikethuai bahwa seksual merupakan kebutuhan bagi banyak individu untuk menurunkan strees dan emosional dengan dilakukannya karantina memungkinkan individu tidak mendapatkan kebutuhan seksualnya dan berakibat disfungsi seksual, juga memiliki efek negatif pada kehidupan seksual seperti melakukan mastrubasi, di keduanya pria dan wanita ${ }^{13}$.

Penelitian ini sejalan dengan penelitian yang dilakukan oleh Loris Marin1*, Alessandra Andrisani1 , Giovanni Buzzaccarini1 , Giampiero Capobianco2, Francesco Dessole2, Eugenio Ragazzi3, Giulia Manzin4, Stefania Mannarini4, Guido Ambrosini1 1 yang menumakan hasil Di antara peserta karantina yang melanjutkan untuk terlibat dalam aktivitas seksual, 52,04\% melaporkan peningkatan setidaknya satu dari 14 aktivitas seksual: 145 orang $(25,66 \%)$ dilaporkan lebih sering masturbasi sendiri. 114 orangS $(20,18 \%)$ melaporkan melakukan lebih banyak hubungan seksual dengan pasangannya, dan 110 orang $(19,47 \%)$ melaporkan menonton lebih banyak pornografimereka sendiri. Namun, tiga aktivitas seksual yang sama juga penurunan frekuensi untuk beberapa peserta.

Mastrubasi merupakan jalan alternative pada pasien covid 19 yang sedang masa perawatan atau karantina seperti penelitian tentang pasien yang sedang mengalami masa karantina memiliki kebutuhan jasmani dan rohani belum terpenuhi. Dengan melakukan mastrubasi dapat menyebabkan penurunan seksual pada seseorang individu. Penelitian ini sejalan dengan penelitian yang dilakukan oleh Michele Carlo Schiavi, MD, PhD,1,2 Vincenzo Spina, MD,1 Marzio
Angelo Zullo, MD, PhD,3 Vanessa Colagiovanni, MD, PhD,2 Paolo Luffarelli, MD,3 Rocco Rago, MD,4 and Pierluigi Palazzetti, MD1 dengan hasil 89 pasien dipertimbangkan. Usia rata-rata adalah 39 (28e50) tahun. Rata-rata hubungan seksual/bulan menurun dari $6,3 \pm 1,9$ menjadi 2,3 $\pm 1,8$, selisih rata-rata: $3,9 \pm$ 1,2. FSFI menurun secara signifikan $(29,2$ $\pm 4,2$ vs $19,2 \pm 3,3$, perbedaan rata-rata: 9,7 \pm 2,6) dan FSDS meningkat secara signifikan $(9,3 \pm 5,5$ vs $20,1 \pm 5,2$, rata-rata perbedaan: $\quad 10,8 \pm 3,4)$. SF-36 menunjukkan perubahan yang signifikan dari $82,2 \pm 10,2$ menjadi $64,2 \pm 11,84$ minggu setelah pengenalan tindakan pembatasan; perbedaan rata-rata: 17,8 \pm 6,7 .

Masih belum ditemukan solusi yang tepat dalam masalah pengaruh covid-19 dengan disfungsi seksual. Penelitian ini lebih lanjut diperlukan untuk menentukan pengaruh covid 19 terhadap disfungsi seksual ${ }^{14}$. Hal ini sejalan dengan penelitian yang dilakukan oleh Jessamyn Bowling 1, *, Erika Montanaro 2 , Sarai GuerreroOrdonez 1, Stuti Joshi 1 and Diana Gioia 1 Sebagian besar studi COVID-19 yang dilakukan hingga saat ini berfokus pada penilaian dampak pandemi terhadap kesehatan fisik. Hal ini mendorong kita untuk merenungkan mental dan seksual konsekuensi yang kami anggap sama pentingnya.

\section{Daftar Pustaka}

Liu N, Zhang F, Wei C, et al. Prevalence and predictors of PTSS during COVID-19 outbreak in China hardest-hit areas: Gender differences matter. Psychiatry research 287 (2020): 112921

Kementrian Kesehatan Indonesia. Data Covid-19 Indonesia 31 Juli 2021

Torales J, O'Higgins M, Castaldelli-Maia JM, Ventriglio A. The outbreak of COVID19 coronavirus and its impact on global mental health. Int $\mathbf{J}$ Soc Psychiatry. 2020;66:317-20.

World Health Organization. Naming the coronavirus disease (COVID-19) and the virus that causes it. World Health Organization;2020.https://www.who.int/e

\footnotetext{
${ }^{13}$ World Health Organization. Sexual and reproductive health: defining sexual health. WHO; 2006. https://www.who.int/ reproductivehealth/topics/sexual_health/sh_defini tions/en/.
}

\footnotetext{
${ }^{14}$ McCabe, M.P.; Connaughton, C. Sexual dysfunction and relationship stress: How does this association vary for men and women? Curr. Opin. Psychol. 2017, 13, 81-84. [CrossRef]
} 
mergencies/diseases/novelcoronavirus-

2019/technical-guidance/naming-the-

coronavirusdisease-(covid-2019)-and-the-

virus-that-causes-it

World Health Organization. Sexual and reproductive

health: defining sexual health. WHO; 2006.https://www.who.int/reproductivehealth/topic s/sexual_health/sh_definitions/en/.

Kroenke K, Spitzer RL, Williams JB. The PHQ-9: validity of a brief depression severity measure. J Gen Intern Med. 2001;16: 606-13

Dunn KM, Croft PR, Hackett GI. Association of sexual problems with social, psychological, and physical problems in men and women: a cross sectional population survey. $\mathrm{J}$ Epidemiol Community Health. 1999;53:144-8.

World Health Organization. Sexual and reproductive health: defining sexual health. WHO; 2020.https://www.who.int/reproductivehealth/topic s/sexual_health/sh_definitions/en/.

McCabe, M.P.; Connaughton, C. Sexual dysfunction and relationship stress: How does this association vary for men and women? Curr. Opin. Psychol. 2017, 13, 81-84. [CrossRef] 